\title{
Ranging pattern and population composition of Rhinopithecus bieti at Xiaochangdu, Tibet: Implications for conservation
}

\author{
XIANG ZuoFu ${ }^{1,2}$, XIAO Wen $^{3}$, HUO Sheng ${ }^{3} \&$ LI Ming ${ }^{4 *}$ \\ ${ }^{1}$ College of Life Science and Technology, Central South University of Forestry \& Technology, Changsha 410004, China; \\ ${ }^{2}$ Kunming Institute of Zoology, Chinese Academy of Sciences, Kunming 650223, China; \\ ${ }^{3}$ Institute of Eastern-Himalaya Biodiversity Research, Dali University, Dali 671000, China; \\ ${ }^{4}$ Key Laboratory of Animal Ecology and Conservation Biology, Institute of Zoology, Chinese Academy of Sciences, Beijing 100101, China
}

Received July 12, 2012; accepted October 29, 2012; published online January 9, 2013

\begin{abstract}
We studied the ranging pattern of the wild black-and-white snub-nosed monkeys (Rhinopithecus bieti) at Xiaochangdu, Tibet from June 2003 to March 2005. Using the map grid cell method, the group home range were $16.75 \mathrm{~km}^{2}$ in summer, $10.50 \mathrm{~km}$ in winter, and $21.25 \mathrm{~km}^{2}$ total over two years. The daily travel length (DTL) averaged $765 \mathrm{~m}$ with a range of $350-3500 \mathrm{~m}$. The results showed that DTL in winter was significantly shorter than those of in summer and spring. Temperature, rainfall, food availability, and human disturbance correlated positively with DTL. According to the maximum observed group size and estimated total home range, population density and biomass of $R$. bieti were 9.1 individuals $/ \mathrm{km}^{2}$ and $88.6 \mathrm{~kg} / \mathrm{km}^{2}$, respectively. The temporal and spatial variations of food resources and patterns of human disturbance largely determine the ranging behavior of $R$. bieti at Xiaochangdu.
\end{abstract}

population density, daily range size, Rhinopithecus bieti, daily travel length

Citation: Xiang Z F, Xiao W, Huo S, et al. Ranging pattern and population composition of Rhinopithecus bieti at Xiaochangdu, Tibet: Implications for conservation. Chin Sci Bull, 2013, 58: 2212-2219, doi: 10.1007/s11434-012-5618-9

Seasonal variations of food availability are known to influence non-human primates' ranging behavior as measured by daily travel length, seasonal home range size, and intensity of habitat use [1-8]. Such fluctuations can occur in both tropical and temperate forests, but seasonal food scarcity in temperate forests is more pronounced than that in tropical forests in terms of plant productivity and diversity $[9,10]$. As a result, primates inhabiting temperate environments must adjust their ranging pattern to deal with low temperature and food shortage in winter to a greater degree than their tropical counterparts. Temperate-living primates have been observed to adopt one of two strategies to balance their energetic costs and caloric expenditure during winter [11-13]. The "high-cost, high-returns" strategy involves greater investment in travel and foraging effort, expending more calories in order to improve access to high quality

*Corresponding author (email: lim@ioz.ac.cn) foods. This strategy is considered to be less common in primates [14-16]. The alternative, more widely employed "energy-saving" strategy is manifested in a broadening of the diet to include less preferred fallback foods while traveling less each day to conserve energy [17-20]. Between these two strategies, a diverse pattern of ranging behavior can be observed in temperate primates confronted with the stresses of food scarcity, nutritional deficits, and low ambient temperature during winter. Examining the ranging behavior of primates living in extreme habitats (e.g. at high altitude) can improve our understanding of ecological adaptations, which is relevant to developing conservation strategies for endangered primates living in temperate zones.

Anthropogenic habitat disturbance such as selective logging often produces areas of resource scarcity [21] similar to that which may be experienced by primates during lean seasons. Specifically, daily travel distance (DTL) and home range have been proved to covary with habitat quality: spe- 
cies dwelling in less abundant habitats occupy a greater area and travel further in order to meet their nutritional requirements [18,22-28]. Therefore, primate groups inhabiting areas subject to periodic human disturbance are expected to have lower population density and biomass than groups in undisturbed areas although primates adapted to human being in Southeast Asia have a high population density and biomass.

The black-and-white snub-nosed monkey (Rhinopithecus bieti, Colobinae) is narrowly distributed within the Chinese provinces of Xizang (Tibet) and Yunnan. Its distribution stretches latitudinally from Zhina $\left(29^{\circ} 20^{\prime} \mathrm{N}\right)$ to Mt. Longma $\left(26^{\circ} 14^{\prime} \mathrm{N}\right)$ and is confined by the upriver of Mekong River (Lancangjiang) and Yangtze River (Jinshajiang) [29,30]. At present, totaling approximately 2500 individuals or 17 groups are known in the wild [31]. The IUCN Red List classifies this species as endangered [32].

Previous studies of the $R$. bieti population at Xiaochang$\mathrm{du}$, Tibet have found that the monkeys depend on lichens as fallback foods in the winter while consuming primarily non-lichen, higher quality foods in the spring, summer, and autumn [33]. Diversity of available foods was found to be higher in secondary forest of selectively logging had occurred in conifer forest, resulting in heavier use of this habitat type by the monkey groups [34]. Thus, the evidence as to whether the ranging behavior of the Xiaochangdu monkeys conforms to theoretical predictions regarding adaptation to disturbed environments is equivocal. In this paper we present new data on seasonal home range and DTL of the Xiaochangdu group and their relationship with climatic parameters such as temperature and food availability in the hopes of clarifying how primates may adapt to environmental stress. We predict that monkeys will have longer daily travel length (DTL) during summer, when food is abundant and temperatures are mild, than in winter, when conserving energy becomes a priority. We also provide calculations of population density and biomass based on our range size estimates and group counts. We also predict that the group of $R$. bieti at this site has a lower population density and biomass than those in undisturbed or less stressful environments (Xiaochangdu has lower plant species richness and a prolonged snowy season compared to southern populations). Finally we compared the population parameters identified for Xiaochangdu with those of other populations and discussed the implications for primate conservation.

\section{Methods}

The study was performed at Xiaochangdu $\left(29^{\circ} 15^{\prime} \mathrm{N}, 98^{\circ} 37^{\prime} \mathrm{E}\right)$ in Honglaxueshan National Nature Reserve (HNNR), southeast Tibet. The study site lies in the Mt. Hengduan (TransHimalayas). HNNR occupies the highest latitude at which Rhinopithecus bieti is found-the monkeys' vertical range here lies at elevations between 3550 and $4300 \mathrm{~m}$. The sea- sonal climate is moist, warm air in summer and cold, dry air in winter. Annual rainfall are $740 \mathrm{~mm}$. July is the wettest month (231 mm rainfall); November is the driest $(3 \mathrm{~mm})$. Annual mean temperature is $4.7^{\circ} \mathrm{C}$. The highest monthly mean temperature $\left(12.5^{\circ} \mathrm{C}\right)$ is in August; and the lowest mean temperature $\left(-3.6^{\circ} \mathrm{C}\right)$ is in January. We recorded a high temperature of $26.9^{\circ} \mathrm{C}$ in August and a low of $-15.4^{\circ} \mathrm{C}$ in January. We defined biological seasons at HNNR based on the mean monthly temperature instead of the standard definitions of seasons for the north temperate latitudes: winter includes those months with mean temperature less than $0^{\circ} \mathrm{C}$, whereas summer includes months with mean temperature greater than $10^{\circ} \mathrm{C}$ [35]. Based on this system, April and May belong to spring, Jun, July and August belong to summer, and September and October belong to autumn. November, December, January, February and March belong to winter. We feel that demarcating the seasons in this way is more relevant to the physical conditions actually experienced by wildlife.

The researchers and villagers never provide any food to the monkeys. More than 400 Tibetan villagers border the monkeys' habitat; none of these villages are found at elevations higher than $3800 \mathrm{~m}$. Hunting is prohibited in the monkeys' habitat. Selective logging to extract firewood and home-building material occurs in the lower altitudes (3800$4000 \mathrm{~m}$ a.s.1.) near the village [34].

Between June 2003 and March 2005, approximately 253 d spend in the field and Xiaochangdu group was tracked for 232 d [29]. This study includes four discontinuous study periods during which the subjects were tracked for at least 30 d: June 16-August 15 (60 d) and October 24-December 28 (61 d) in 2003, March 2-April 7 (37 d) in 2004, and January 25-March 28 (63 d) in 2005.

\section{Data collection and analysis}

\subsection{Ranging patterns}

The monkeys were located based on their sleeping site in the previous day. The monkeys were tracked via visual or auditory clue (call of the monkeys and sound of breaking branches when the monkeys moved between the tree crowns). Daily observation was conducted once we tracked the monkeys until they ranged out of sight.

We superimposed a grid of $500 \mathrm{~m} \times 500 \mathrm{~m}$ cells onto a 1:100000 scale topographical map and located group centroids via visual or auditory clue with the aid of GPS points and landmarks. Seasonal home range was measured as the area at which new grid cells used reached an asymptote during a certain study period. The tree with the maximum individuals stayed was considered as the group center. We recorded the location of the group's centroid every $2 \mathrm{~h}$ via GPS receiver, unless we were prevented from doing so by dense vegetation or deep valley. We marked the group's location on the map and used these records to estimate the 
group's daily travel length (DTL), defined as the distance between the sleeping sites on two consecutive days along the path demarcated by group centroids. If the monkeys were not followed in the morning when they left the sleeping sites, we estimated DTL from the foraging trails according to signs such as broken branches or freshly fallen feces. We only used the ranging data collected between June 17 and August 15 (summer, $60 \mathrm{~d}$ ) and between October 29 and December 27 (early winter, $61 \mathrm{~d}$ ) to estimate seasonal home range. The cumulative curve of new grid cells entered reached an asymptote in these seasons (Figure 1).

\subsection{Environmental parameters and human disturbance}

We recorded climatic data at $3800 \mathrm{~m}$ from the study camp using HOBO equipment [33]. The crown density method [36] was used to monitor food availability. Potential food items of different plant parts were monthly estimated by visual examination of the tagged plants for the emergent buds, young leaves, mature leaves, or flowers. The assumed item was allocated a relative abundance value with $0,1,2$ and 3. The " 0 " represented no emergent for that plant item; "1" represented plant item occupied $<25 \%$ of the crown, "2" represented it occupied $25 \%-50 \%$ of the crown, and " 3 " represented it occupied $>50 \%$. Livestock were not seen to influence monkey ranging patterns at the study site (Xiang $\mathrm{ZF}$, personal observation). As a result, we recorded whether people were observed inside the habitat forest to get a rough evaluation of how people's presence might affect ranging pattern. The numbers of villager who went into the forestry via the path along study camp were used to estimate human disturbance. We counted at least three days per month, which were assigned in different period of every month [29].

\subsection{Group composition and estimates of population parameters}

From June 2003 to March 2005, we conducted opportunistic censuses when the monkeys crossed open land. We typically observed the monkeys at distances around $100 \mathrm{~m}$, varying between 50 and $200 \mathrm{~m}$. As reliably identify individuals in the group was not available, the monkeys were classified into the different sex/age classes based on coat color, body size, and other traits: adult males, adult females, juveniles of both sexes, and infants $[37,38]$.

\subsection{Data analysis}

We used the data from all four study periods to calculate yearly home range and monthly average DTL. Autumn data was limited to only six days of behavioral records. We used one-way ANOVA to test whether the variation in ranging behavior could be explained by season, measured environ- mental parameters such as temperature, rainfall, and food availability, and/or human disturbance. We performed a $t$-test to compare DTL between summer and winter. We used spearman's rank correlation to test the relationships among the measures of DTL, environmental parameters (temperature, rainfall, food availability), and human disturbance, respectively.

Population density Rhinopithecus bieti at Xiaochangdu were calculated by dividing the maximum observed group count obtained from the all censuses by the estimated annual home range area. We then estimated their biomass by multiplying the population density by mean adult body mass (9.1 kg for calculating the biomass [38]).

SPSS 13.0 was used in statistical analyses. All tests were two-tailed; $P<0.05$ was taken as significance level.

\section{Results}

\subsection{Seasonal range size and yearly home range}

Cumulative curves of new grid cells entered by the focal group for each of the four study periods are presented in Figure 1. Only during the summer (June 17-August 15, Figure 1(a)) and the winter (October 29-December 27, Figure 1(b)) did the curve reach an asymptote. The seasonal home range sizes for these two seasons are 16.75 and $10.5 \mathrm{~km}^{2}$, respectively (Figure 2). In summer, the monkeys ranged widely, using 67 cells and occupying 79\% of their total home range. Reuse frequency of cells (entries per grid cell) was 2.8 ( $\mathrm{SD}=1.9$, range 1-12). In winter, the monkeys entered only 42 grid cells, occupying $49 \%$ of the total home range. Reuse frequency of grid cells was higher $(3.9, \mathrm{SD}=$ 3.5 , range 1-16) than in summer, indicating more intensive use of certain areas during winter.

The cumulative curve of new grid cells entered by the focal group over the entire study period is presented in Figure 3. The monkeys' home range was estimated to be 21.25 $\mathrm{km}^{2}$ based on their use of 85 total grid cells. Frequently used areas (used either $\geqslant 5$ times or $\geqslant 1 \%$ of the total) accounted for 51 cells or $12.75 \mathrm{~km}^{2}$; this area constituted $85 \%$ of all grid cell entries and about $60 \%$ of the total home range.

\subsection{Seasonal variability in ranging pattern}

The mean DTL of the study group was $765 \mathrm{~m}$ (range $=350$ $3500 \mathrm{~m}, \mathrm{SD}=344$ ). Mean DTL was shortest between December and March, during which time the monkeys fed primarily on lichens. The longest mean DTL approached $1 \mathrm{~km}$ in May when many preferred food items were available and many local people wandered the forest to collect mushrooms or plants used in Chinese medicine. Monthly mean DTL differed significantly across the seasons (oneway ANOVA, $\left.\mathrm{F}_{11,183}=7.46, P<0.001\right)$. Post hoc pairwise comparisons detected significant differences between spring 

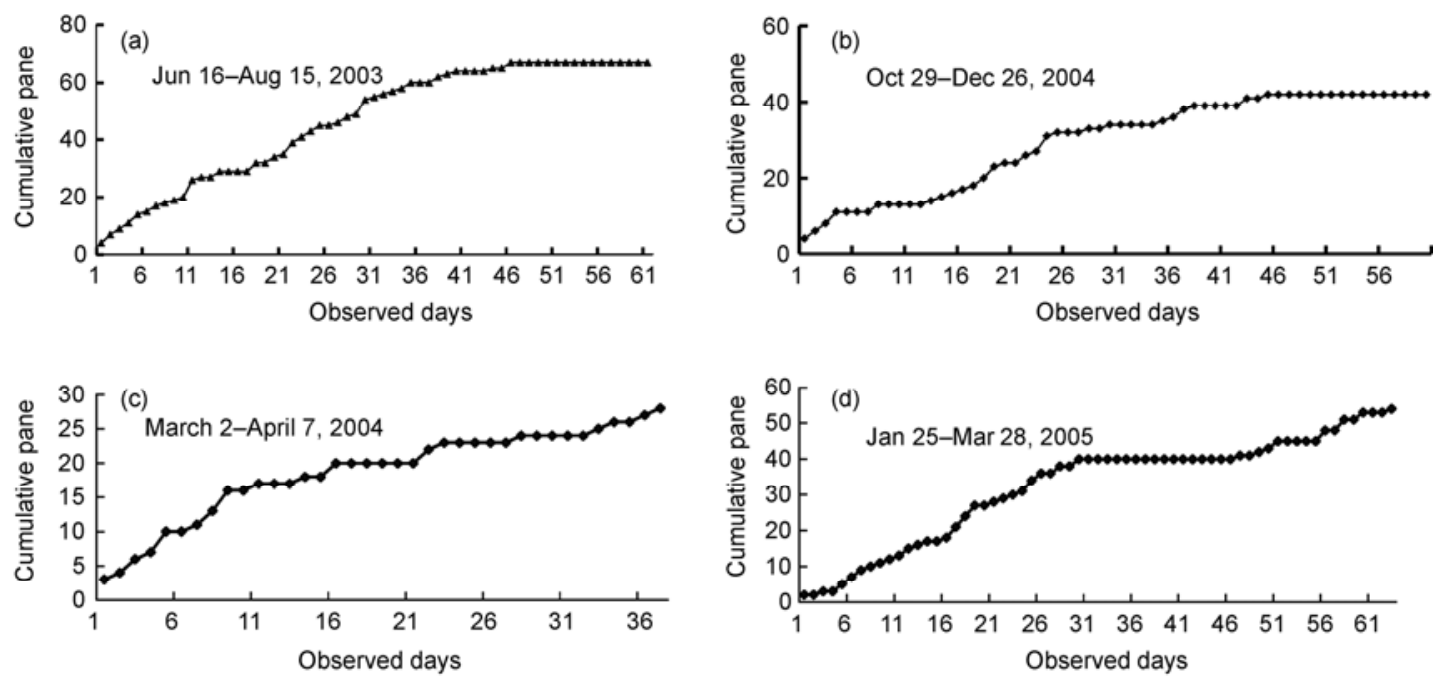

Figure 1 Cumulative number of map grid cells entered by the monkey group during each of the four study periods.

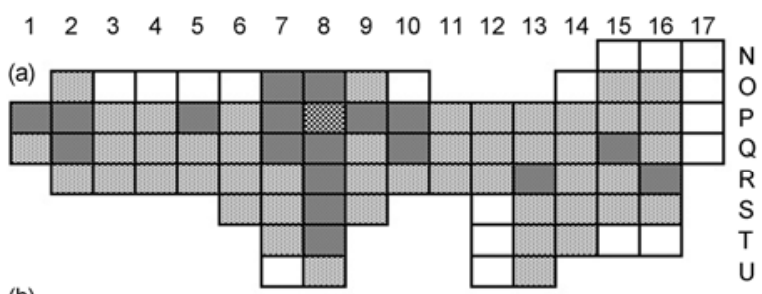

(b)

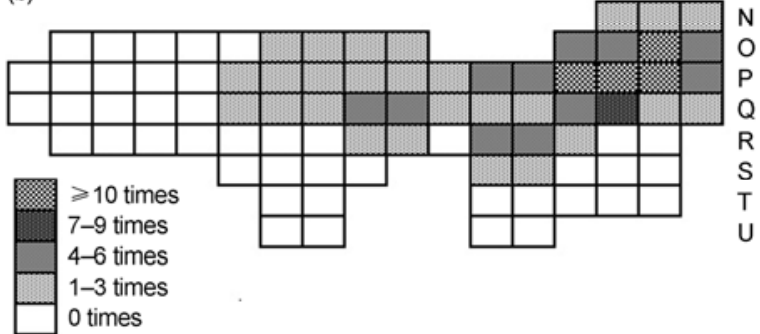

Figure 2 Range use of Rhinopithecus bieti at Xiaochangdu over two different seasons. (a) Summer; (b) early winter. Blank grid squares fell within the yearly home range of this population but were not used during these two seasons.

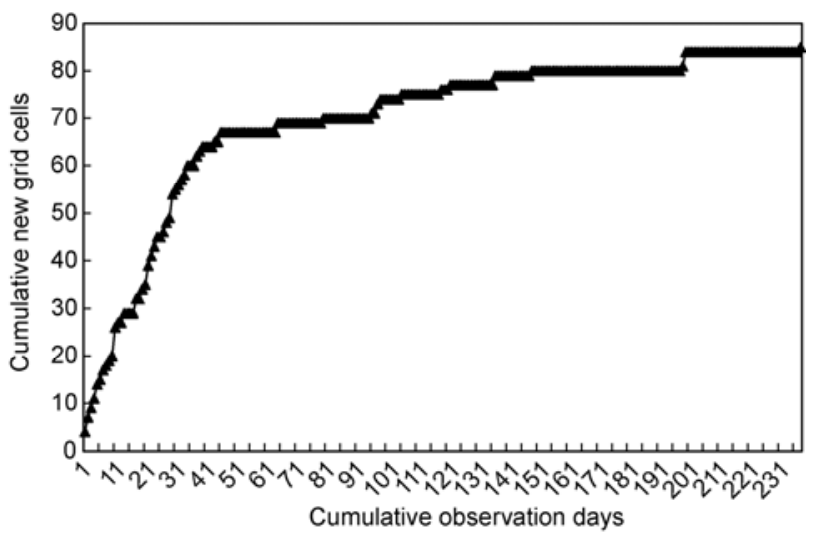

Figure 3 Cumulative number of map grid cells entered by the monkey group during the entire study period. and winter (LSD, $P<0.05$, Figure 4 ) and between summer and winter (LSD, $P<0.001$, Figure 4). Human disturbance was observed to influence daily travel length: on August 14, 2003, the monkeys changed their direction of travel five times, moving a total of almost $3.5 \mathrm{~km}$, due to an abundance of people collecting Matsutake mushrooms (Tricholoma matsutake) in the forest.

\subsection{Relationships among ranging behavior, environmental parameters, and human disturbance}

Correlations between DTL and environmental factors (temperature, rainfall, and food availability) and between DTL and human disturbance appear in Table 1. There were positive correlations between daily travel length and temperature (Spearman's rank correlation test, $r_{\mathrm{s}}=0.689, P<0.05$ ), food availability $\left(r_{\mathrm{s}}=0.766, P<0.01\right)$, rainfall $\left(r_{\mathrm{s}}=0.646, P<\right.$ $0.05)$ and human disturbance $\left(r_{\mathrm{s}}=0.734, P<0.01\right)$. These correlations indicate a strong positive relationship between the external influences described above and the monkey's travel length in a given day.

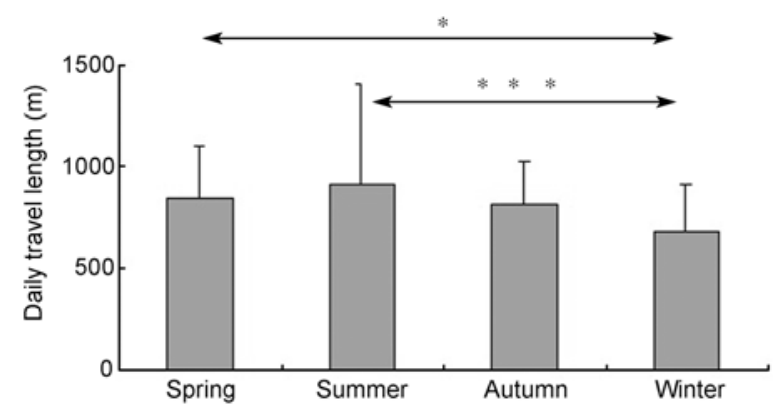

Figure 4 Average daily travel length of one group of Rhinopithecus bieti at Xiaochangdu. Horizontal lines indicate significant post hoc difference. LSD, $* P<0.05$; *** $P<0.001$. 
Table 1 Spearman rank correlations between ranging behavior of Rhinopithecus bieti and environmental factors at Xiaochangdua)

\begin{tabular}{lcccc}
\hline & Temperature & Rainfall & $\begin{array}{c}\text { Food } \\
\text { availability }\end{array}$ & $\begin{array}{c}\text { Human } \\
\text { disturbance }\end{array}$ \\
\hline Daily range size & $0.656^{*}$ & $0.575^{\text {ns }}$ & $0.819^{* * *}$ & $0.834^{* *}$ \\
Daily travel length & $0.689^{*}$ & $0.646^{*}$ & $0.766^{* *}$ & $0.734^{* *}$ \\
\hline
\end{tabular}

a) ns: not significant; $* P<0.05$; ** $P<0.01$; *** $P<0.001$.

\subsection{Group composition and estimates of population parameters}

During the study period, we had four opportunities to census the focal group while the monkeys crossed an open area (Table 2). The largest group count we obtained consisted of 207 monkeys. Group composition by age/sex class included 32 adult males, 71 adult females, 72 juveniles of both sexes, and 32 infants of both sexes. The ratio of male to female was $1: 2.2$. The ratio of adults of both sexes to immatures (including both juveniles and infants) was $1: 1$, while the ratio of infants of both sexes to adult females was $1: 2.3$. These demographic data indicate a stable population at Xiaochangdu.

Using the maximum population estimate of 207 individuals and the total home range estimate of $21.25 \mathrm{~km}^{2}$, the biomass and population density of $R$. bieti at Xiaochangdu were $88.6 \mathrm{~kg} / \mathrm{km}^{2}$ and 9.7 individuals $/ \mathrm{km}^{2}$, respectively.

\section{Discussion}

\subsection{Seasonal variability in ranging pattern}

Food availability may be the most significant factors that influenced primate species' ranging pattern [7,8]. When food items show a patchy distribution, group-living primates are expected to travel extensively $[39,40]$. Furthermore, during seasons when preferred food is widely available, primates are predicted to expand their range (employing the "high-risk, high-reward" strategy) [11]. Lichens, the fallback food for $R$. bieti, are shortage of protein [37]. Feeding on non-lichen items (fruits, nuts, and leaves) during the warmer months may be a strategy to meet the protein requirement, although it has been found that colobine monkeys may obtain protein from intestinal bacteria during the physical process in fermentation of cellulose [41,42]. At Xiaochangdu, the monkeys' most preferred food items are

Table 2 Census data over four opportunistic observations

\begin{tabular}{|c|c|c|c|c|c|c|c|c|}
\hline & Male & Female & Juvenile & Infant & Total & $\mathrm{OMU}^{\mathrm{a}}$ & $\mathrm{MMU}^{\mathrm{b})}$ & $\mathrm{AMU}^{\mathrm{c})}$ \\
\hline Jul 23, 2003 & 17 & 54 & 49 & 19 & 139 & 13 & 2 & 0 \\
\hline Dec 15, 2003 & 32 & 71 & 72 & 32 & 207 & 15 & 4 & 1 \\
\hline Mar 7, 2005 & 6 & 27 & 42 & 9 & 84 & 6 & 0 & 0 \\
\hline Mar 15, 2005 & 15 & 47 & 59 & 19 & 140 & 15 & 0 & 0 \\
\hline
\end{tabular}

a) One male, multi-female unit; b) multi-male, multi-female unit; c) all male unit. young leaves, flowers, fruits, and nuts [33]. These items are seasonally available in the forest understory from May to September [33]. Our results indicate that (i) DTL was positively correlated with food availability (Table 1); (ii) R. bieti had a significantly longer DTL in summer and spring than in winter (Figure 4); and (iii) the monkeys had both a larger home range in the summer and a lower reuse rate for each grid cell. These results are consistent with observations of $R$. bieti living at other localities (Table 3 ). For example, Kirkpatrick et al. [43] and Liu et al. [44] found that $R$. bieti had a larger home range during summer and traveled further each day when preferred foods were available. Our results are also consistent with studies of $R$. roxellana which report that DTL increases significantly in autumn and summer when food available is high [45-47]. This study supports the hypothesis that both the amount of travel required to find fruits and the time and energy available for traveling increase as the fruits in the diet increase [48]. However, it is important to emphasize that DTL and range size are separate metrics that can change independently. For instance, $R$. bieti at Samage ranged over a more limited area in autumn, when fruit available is highest because the monkeys' preferred fruit occurred at high densities in small clumps which ripened synchronously. This caused the monkeys to repeatedly forage in the same patches, increasing daily travel distance without increasing range size [49].

In addition, human disturbance has an unneglected effect on ranging behavior at Xiaochangdu (Table 1). We encountered hundreds of local people collecting non-timber forest products such as mushrooms and medicinal plants from mid-May to early October [29]. During summer, the peak season for the collection of Matsutake mushrooms, people constantly wandered throughout the monkeys' home range. Human activity within monkey habitat generally results in longer daily travel distances. Groups of $R$. roxellana at Shennongjia were found to travel further than normal to avoid human disturbance [50]. Longer travel distances result in greater energy expenditure, which may impact the monkeys' reproduction and survival in the long term. However, the period of intensive human activity at Xiaochangdu coincides with the greatest availability of preferred food for the monkeys, which may help to mitigate any negative impacts on the population.

\subsection{Home range and population density}

In general, range size is affected by population density, body size and group size characteristic of a species [1,51,52]. To satisfy the nutritional and energetic requirements, groupliving primates with larger body size and/or larger group size occupy relatively larger home ranges than those of species having smaller body size and/or group size [53-56]. The Chinese snub-nosed monkeys are large-bodied, especially compared with other colobines, and often live in large groups of more than 100 individuals. We found a significant 
positive correlation (Spearman's rank correlation, $r_{\mathrm{s}}=0.852$, $P<0.001, n=11)$ between group size and home range among these snub-nosed monkey species (Table 3). The home range of the Xiaochangdu group is approximately $21.25 \mathrm{~km}^{2}$; the larger home range is consistent with other studies of $R$. bieti $[43,44,49,57,58]$ as well as $R$. roxellana and $R$. brelichi (Table 3).

High-altitude, temperate habitats with pronounced seasonal fluctuations in food availability may require greater travel on the part of resident primates in order to maintain a positive energy balance due to the unique phenology of these environments. In accordance with this expectation, temperate primates have larger home ranges than tropical conspecifics $[59,60]$. This trend holds insofar as odd-nosed colobines living in temperate zones have larger ranges than do odd-nosed colobines in tropical zones [37]. A group of $R$. bieti at Wuyapiya, about $100 \mathrm{~km}$ south of Xiaochangdu, had a home range of $25 \mathrm{~km}^{2}$ [43]. Another group of $R$. bieti with $>410$ individuals living to the south in the Samage Forest, Yunnan, had a home range of $25 \mathrm{~km}^{2}$ [49], while a group of approximately 180 individuals occupied $23.3 \mathrm{~km}^{2}$ at Jinsichang, Yunnan [58]. Generally speaking, complex vegetation profiles mean high food availability and high population density for leaf-eating monkeys. The habitat of $R$. bieti shows a tendency of increasing plant diversity with decreasing latitude [33]. Thus, the Xiaochangdu group experiences reduced botanical species richness and more inclement weather including blizzards and freezes than southern populations. However, our results indicate that the Xiaochangdu group has a higher population density/biomass than more southerly populations with the exception of Sa- mage. Greater levels of human disturbance at those sites, such as habitat destruction through wood extraction, illegal mining, and poaching (Mt. Longma: [57]; Mt. Fuhe: [44]), may account for this difference and keep these populations below the carrying capacity of the environment. Local Tibetan Buddhist beliefs serve to protect monkey populations at Xiaochangdu from suffering similar hardships; it is taboo to kill any living creature on the sacred mountains. Our study group may be only stable sub-population left since the last survey in 1988 [29], having reached carrying capacity. Optimism may still be warranted in the case of the other $R$. bieti groups, as conservation policies put into place during the 1990s may have allowed for habitat recovery during the 2000s [44,57]. It is reasonable to conclude that the groups at more southerly sites might be in a growth phase.

\subsection{Conservation implications}

Anthropogenic disturbances such as habitat alteration or improper behavior toward the monkeys appear to influence ranging patterns and habitat use in $R$. bieti at Xiaochangdu, Tibet. While commercial logging is known to have a negative impact, low-intensity selective logging may result the disturbance areas into gradually recover to climax stages of successional vegetation and provide $R$. bieti with a greater variety of foods [34]. The black-and-white snub-nosed monkey at Xiaochangdu has stabilized two decades suggests that human disturbance has had few negative impacts on the monkeys' survival, and that the population may be near carrying capacity as the group has stable for about 20 years since 1987. We are optimistic that, due to the specific

Table 3 Comparative data on home range, population density, biomass, and daily travel distance of Rhinopithecus spp. at multiple Chinese localities

\begin{tabular}{|c|c|c|c|c|c|c|c|}
\hline Species/sites & $\begin{array}{c}\text { Home range } \\
\left(\mathrm{km}^{2}\right)\end{array}$ & $\begin{array}{c}\text { Daily travel } \\
\text { length }(\mathrm{m})\end{array}$ & Group size & $\begin{array}{l}\text { Population density } \\
\text { (individuals } / \mathrm{km}^{2} \text { ) }\end{array}$ & $\begin{array}{c}\text { Biomass }{ }^{\mathrm{a})} \\
\left(\mathrm{kg} / \mathrm{km}^{2}\right)\end{array}$ & Vegetation types $^{\text {b) }}$ & Reference \\
\hline \multicolumn{8}{|l|}{ R. bieti } \\
\hline Xiaochangdu & 21.25 & 765 & 207 & 9.7 & 88.6 & 12 & This study \\
\hline Wuyapiya & 25.25 & 1311 & 175 & 6.9 & 63.1 & 12 & [43] \\
\hline Samage & 25 & 1514 & 410 & 12.8 & 106.6 & 123 & [49] \\
\hline Jinsichang & 23.3 & & 180 & 7.7 & 70.3 & 123 & [58] \\
\hline Fuheshan & 10.7 & 800 & 80 & 7.5 & 68.0 & 1234 & {$[44]$} \\
\hline Longmashan & 9.56 & & 80 & 8.4 & 76.2 & 1234 & {$[57]$} \\
\hline \multicolumn{8}{|l|}{$R$. roxellana } \\
\hline Zhouzhi West Ridge & 22.5 & & 90 & 4.0 & 37.60 & 134 & {$[61]$} \\
\hline Zhouzhi East Ridge & 18.3 & 2100 & 112 & 6.1 & 58.1 & 134 & [46] \\
\hline Qingmuchuan & 20.35 & 837 & 120 & 5.9 & 55.4 & 234 & $\begin{array}{l}\text { [47]; Li Y K, personal } \\
\text { communication }\end{array}$ \\
\hline \multicolumn{8}{|l|}{ R. brelichi } \\
\hline Fanjingshan & 35 & 935 & 400 & 11.4 & 89.1 & 234 & $\begin{array}{l}\text { Xiang Z F (unpublished } \\
\text { data) }\end{array}$ \\
\hline
\end{tabular}

a) Calculated using average weights of $9.1 \mathrm{~kg}$ for $R$. bieti, $9.4 \mathrm{~kg}$ for $R$. roxellana, and $7.8 \mathrm{~kg}$ for $R$. brelichi [37]. b) 1, conifer forest; 2 , evergreen broadleaf forest (oak forest); 3, mixed conifer-broadleaf forest; 4 , deciduous broadleaf forest. 
ecology of Xiaochangdu and the specific culture of neighbouring Tibetans, the right management strategies can foster a sustainable ecosystem which provides for both humans and monkeys.

This work was supported by the National Natural Science Foundation of China (31071937), the State Forestry Administration of China, and the Project of Public Benefit for Forestry (201104073). Thanks are given to Ms. Alicia Krzton and Dr. Cyril Gruter for useful suggestions and editing the English manuscript, Ding Z, Ci R, Zhu J, Wang Z, A'Nan and Deng P for helping data collection in the field.

1 Clutton-Brock T H. Ranging behaviour of red colobus (Colobus badius tephrosceles) in the Gombe National Park. Aim Behav, 1975, 23: 706-722

2 Kaplin B A. Ranging behavior of two species of guenons (Cercopithecus lhoesti and $C$. mitis doggetti) in the Nyungwe Forest Reserve, Rwanda. Int J Primatol, 2001, 22: 521-548

3 Digby L J, Barreto C E. Activity and ranging patterns in common marmosets (Callithrix jacchus): Implications for Reproductive Strategies. In: Norconk M A, Rosenberger A L, Garber P A, eds. Adaptive Radiations of Neotropical Primates. New York: Plenum Press, 1996. 173-185

4 Olupot W, Chapman C A, Waser P M, et al. Mangabey (Cercocebus albigena) ranging patterns in relation to fruit availability and the risk of parasite infection in Kibale National Park, Uganda. Am J Primatol, 1997, 43: 65-78

5 Strier K B. Ranging behavior of woolly spider monkeys, or muriquis, Brachyteles arachnoides. Int J Primatol, 1987, 8: 575-591

6 Achenbach G G, Snowdon C T. Costs of caregiving: Weight loss in captive adult male cotton-top tamarins (Saguinus oedipus) following the birth of infants. Int J Primatol, 2002, 23: 179-189

7 Milton K. The Foraging Strategy of Howler Monkeys: A Study in Primate Economics. New York: Columbia University Press, 1980

8 Chapman C A. Patterns of foraging and range use by three species of neotropical primate. Primates, 1988, 29: 177-194

9 Latham R E, Ricklefs R E. Global patterns of tree species richness in moist forests: energy-diversity theory does not account for variation in species. In: Ricklefs R E, Schluter D, eds. Species Diversity in Ecological Communities: Historical and Geographical Perspectives. Chicago: University of Chicago Press, 1993

10 Cramer W, Kicklighter D W, Bondeau A, et al. Comparing global models of terrestrial net primary productivity (NPP): Overview and key results. Glob Change Biol, 1999, 5: 1-15

11 Norberg P A. An ecological theory on foraging time and energetics and costs of optimal food searching method. J Anim Ecol, 1977, 46: 511-529

12 Stephens D W, Krebs J R. Foraging Theory. Princeton: Princeton University Press, 1986

13 Grueter C C, Li D Y, Ren B P, et al. Dietary profile of Rhinopithecus bieti and its socioecological implications. Int J Primatol, 2009, 30: 601-624

14 Curtin R A. The socio-ecology of the common langur, Presbytis entellus in the Nepal Himalaya. Dissertation for the Doctoral Degree. Berkeley: University of California, 1975

15 Bleisch W. Conservation of the Guizhou golden monkey. In: Xia W, Zhang Y, eds. Primate Research and Conservation. Beijing: China Forestry Publishing House, 1995. 150-156

16 Sayers K, Norconk M. Himalayan Semnopithecus entellus at Langtang National Park. Nepal: diet, activity patterns, and resources. Int J Primatol, 2008, 29: 509-530

17 Nakagawa N. Bioenergetics of Japanese monkeys (Macaca fuscata) on Kinkazan Island during winter. Primates, 1989, 30: 441-460

18 Mènard N, Vallet D. Behavioral responses of Barbary macaques (Macaca sylvanus) to variations in environmental conditions in Algeria. Am J Primatol, 1997, 43: 285-304
19 Ding W, Zhao Q K. Rhinopithecus bieti at Tacheng, Yunnan: Diet and daytime activities. Int J Primatol, 2004, 25: 583-598

20 Guo S, Li B, Watanabe K. Diet and activity budget of Rhinopithecus roxellana in the Qinling Mountains. China. Primates, 2007, 48: 268-276

21 Struhsaker T T. Ecology of An African Rain forest: Logging in Kibale and the Conflict Between Conservation and Exploitation. Gainesville, Florida: University of Florida Press, 1997

22 Ganas J, Robbins M M. Ranging behavior of the mountain gorillas (Gorilla beringei beringei) in Bwindi Impenetrable National Park, Uganda: A test of the ecologiclal constraints model. Behav Ecol Sociobiol, 2005, 58: 277-288

23 Lee R J. The impact of hunting and habitat disturbance on the population dynamics and behavioral ecology of the crested black macaque (Macaca nigra). Dissertation for the Doctoral Degree. Oregon: University of Oregon, 1997

$24 \mathrm{Li} \mathrm{Y,} \mathrm{Liao} \mathrm{M,} \mathrm{Yu} \mathrm{J,} \mathrm{et} \mathrm{al.} \mathrm{Effects} \mathrm{of} \mathrm{annual} \mathrm{change} \mathrm{in} \mathrm{group} \mathrm{size,}$ human disturbances and weather on daily travel distance of a group of Sichuan snub-nosed monkey (Rhinopithecus roxellana) in Shennongjia Nature Reserve, China. Biodiversity Sci, 2005, 13: 432-438

25 Li Z, Rogers M E. Habitat quality and range use of white headed langurs in Fusui, China. Folia Primatol, 2005, 76: 185-195

26 O'Brien T G, Kinnaird M F. Behavior, diet, and movements of the Sulawesi crested black macaque. Int J Primatol, 1997, 18: 321-351

27 Singh M, Kumara H N, Ananda Kumar M, et al. Behavioral responses of lion-tailed macaques (Macaca silenus) to a changing habitat in a tropical rain forest fragment in Western Ghats, India. Folia Primatol, 2001, 72: 278-291

28 Wieczkowski J. Examination of increased annual range of a Tana mangabey (Cercocebus galeritus) group. Am J Phys Anthropol, 2005, 128: $381-388$

29 Xiang Z F, Huo S, Wang L, et al. Distribution, status and conservation strategies of the black-and-white snub-nosed monkey Rhinopithecus bieti in Tibet. Oryx, 2007, 41: 525-531

30 Long Y C, Kirkpatrick R C, Zhong T, et al. Report on the distribution, population, and ecology of the Yunnan snub-nosed monkey Rhinopithecus bieti. Primates, 1994, 35: 241-250

31 Long Y, Wu R. Population, home range, conservation status of the Yunnan snub-nosed monkey (Rhinopithecus bieti). Abstracts of the China Fusui International Primatological Symposium, 2006. 10-11

32 IUCN 2012. IUCN Red List of Threatened Species. Version 2012.1. $<$ www.iucnredlist.org $>$. Downloaded on 25 September 2012

33 Xiang Z F, Huo S, Xiao W, et al. Diet and feeding behavior of Rhinopithecus bieti at Xiaochangdu, Tibet: Adaptations to a marginal environment. Am J Primat, 2007, 69: 1141-1158

34 Xiang Z F, Huo S, Xiao W. Habitat selection of black-and-white snub-nosed monkeys (Rhinopithecus bieti) in Tibet: Implications for species conservation. Am J Primatol, 2011, 73: 347-355

35 Zhang B K. Seasonal distribution in China. Acta Geogr Sin, 1934, 1: $1-18$

36 Marsh C W. Ranging behaviour and its relation to diet selection in Tana River red colobus (Colobus badius rufomitratus). J Zool (Lond.), 1981, 195: 473-492

37 Kirkpatrick R C. Ecology and behavior of the Yunnan snub-nosed langur (Rhinopithecus bieti, Colobinae). Dissertation for the Doctoral Degree. Davis: University of California, 1996

38 Xiang Z F, Huo S, Xiao W, et al. Terrestrial Behavior and forest strata use in a group of black-and-white snub-nosed monkeys (Rhinopithecus bieti) at Xiaochangdu, Tibet. Current Zool, 2009, 55: 180-187

39 Chapman C A, Chapman L J. Dietary variability in primate populations. Primates, 1990, 31: 121-128

40 Oates J F. Food distribution and foraging behavior. In: Smuts B B, Cheney D L, Seyfarth R M, et al. eds. Primate Societies. Chicago: University of Chicago Press, 1987. 197-209

41 Kay R N B, Davies A G. Digestive physiology. In: Davies A G, Oates J F, eds. Colobine Monkeys: Their Ecology, Behaviour, and Evolution. Cambridge: Cambridge University Press. 1994. 229-250

42 Chivers D J. Functional anatomy of the gastrointestinal tract. In: Davies 
A G, Oates J F, eds. Colobine Monkeys: Their Ecology, Behaviour, and Evolution. Cambridge: Cambridge University Press, 1994. 205-227

43 Kirkpatrick R C, Long Y C, Zhong T, et al. Social organization and range use in the Yunnan snub-nosed monkey Rhinopithecus bieti. Int J Primatol, 1998, 19: 13-51

44 Liu Z H, Ding W, Grueter C C. Seasonal variation in ranging patterns of Yunnan snub-nosed monkeys Rhinopithecus bieti at Mt. Fuhe, China. Acta Zool Sin, 2004, 50: 691-696

$45 \mathrm{Li} \mathrm{Y}$. The seasonal daily travel in a group of Sichuan snub-nosed monkey (Pygathrix roxellana) in shennongjia nature reserve, China. Primates, 2004, 43: 271-276

46 Tan C L, Guo S, Li B. Population structure and ranging patterns of Rhinopithecus roxellana in Zhouzhi National Nature Reserve, Shaanxi, China. Int J Primatol, 2007, 28: 577-591

47 Li Y K, Jiang Z G, Li C W, et al. Effects of seasonal folivory and frugivory on ranging patterns in Rhinopithecus roxellana. Int J Primatol, 2010, 31: 609-626

48 Strier K B. Food, foraging and females. Primates Behavioural Ecology. Boston: Allyn and Bacon, 2003

49 Grueter C C, Li D Y, van Schaik C P, et al. Ranging of Rhinopithecus bieti in the Samage Forest, China. I. Characteristics of range use. Int J Primatol, 2008, 29: 1121-1145

$50 \mathrm{Li} \mathrm{Y}$. The effect of forest clear-cutting on habitat use in Sichuan snub-nosed monkey (Rhinopithecus roxellana) in Shennongjia Nature Reserve, China. Primates, 2004, 45: 69-72

51 Olupot W, Chapman C A, Brown C H, et al. Mangabey (Cercocebus albigena) population density, group size, and ranging: A 20 year comparison. Am J Primat, 1994, 32: 197-205

52 Butynski T M. Comparative ecology of blue monkeys (Cercopithecus mitis) in high- and low-density subpopulation. Ecol Monogr, 1990, 60: $1-26$

53 Altmann S A. Baboons, space, time, and energy. Am Zool, 1974, 14: 221-248
54 Chapman C A, Wrangham R W, Chapman L J. Ecological constraints on group size: An analysis of spider monkey and chimpanzee subgroups. Behav Ecol Sociobiol, 1995, 36: 59-70

55 Janson $\mathrm{C} \mathrm{H}$, Goldsmith M L. Predicting group size in primates: Foraging costs and predation risks. Behav Ecol, 1995, 6: 326-336

56 Gillespie T R, Chapman C A. Determinants of group size in the red colobus monkey (Procolobus badius): An evaluation of the generality of the ecological-constraints model. Behav Ecol Sociobiol, 2001, 50: 329-338

57 Huo S. Diet and habitat use of Rhinopithecus bieti at Mt. Longma, Yunnan, and phylogeny of the Family Viverridae in China (in Chinese). Dissertation for the Doctoral Degree. Kunming: Kunming Institute of Zoology, Chinese Academy of Sciences, 2005

58 Ren B P, Li M, Long Y C, et al. Influence of day length, ambient temperature, and seasonality on daily travel distance in the Yunnan snub-nosed monkey at Jinsichang, Yunnan, China. Am J Primatol, 2009, 71: 233-241

59 Bishop N H. Himalayan langurs: temperate colobines. J Hum Evol 1979, 8: 251-281

60 Takasaki H. Troop size, habitat quality, and home range area in Japanese macaques. Behav Ecol Sociobiol, 1981, 9: 277-281

61 Li B, Chen C, Ji W, Ren B. Seasonal home range changes of the Sichuan snub-nosed monkey (Rhinopithecus roxellana) in the Qinling Mountains of China. Folia Primatol, 2000, 71: 375-386

62 Su Y J, Ren R M, Yan K H, et al. Preliminary survey of the home range and range behavior of golden monkeys (Rhinopithecus roxellana) in Shenglongjia National Natural Reserve, Hubei, China. In: Jablonski N G, ed. The Natural History of the Doucs and Snub-nosed monkeys. Singapore: World Scientific Press, 1998. 255-277

63 Xiang Z F, Yu Y, Yang M, et al. Does flagship species tourism benefit conservation? A case study of the golden snub-nosed monkey in Shennongjia National Nature Reserve. Chin Sci Bull, 2011, 56: $2553-2558$

Open Access This article is distributed under the terms of the Creative Commons Attribution License which permits any use, distribution, and reproduction in any medium, provided the original author(s) and source are credited. 